\title{
A SOMA ANÔMALA: A QUESTÃO DO SUPLEMENTO NO XAMANISMO E MENSTRUAÇÃO IKPENG*
}

David Rodgers

Le concept est le contour, la configuration, la constellation d'un événement à venir (Deleuze e Guattari 1991:36).

\section{Introdução}

Este ensaio explora os tópicos do xamanismo e da menstruação na cosmologia dos ikpeng, povo indígena do sul da Amazônia. Atualmente localizada no norte do Parque Indígena do Xingu (na confluência dos rios Xingu e Iamaçu), a população, que conta em torno de 240 pessoas, vive principalmente do cultivo de roças, da caça e da pesca. Sua língua faz parte do complexo arara, subgrupo da família lingüística caribe. Com efeito, a despeito de estarem há cerca de um século geograficamente mais próximos do complexo Alto-Xinguano - contra o qual se mantiveram em guerra por grande parte do tempo - , pode-se dizer que culturalmente os Ikpeng convergem mais para os próprios Arara do rio Iriri (Teixeira-Pinto 1997) e para outros povos caribe do norte da Amazônia e das Guianas. Pretendo explorar alguns desses pontos de convergência ao longo do presente artigo.

Antes do seu deslocamento para o PI Xingu, os Ikpeng foram infamados pela região por conta de seus esporádicos ataques e capturas de crianças inimigas - estas desejadas como futuros cônjuges e progenitores $^{1}$. Os motivos evocados pelos Ikpeng de hoje como explicação para esses ataques são tanto reativos quanto pró-ativos - vingança pelas mortes ikpeng causadas por guerra ou feitiçaria externa e/ou desejo (aparentemente espontâneo) de fazer guerra e rapto. Essa ambivalência aponta para uma lógica da suplementaridade, cuja implicação paralela é a atração ikpeng pelo perigo. Tal inclinação vertiginosa corta transversalmente sua cultura e exige uma teoria da guerra que se baseie não em uma autopreservação do ser orgânico (a pessoa humana íntegra), mas na exposição des- 
te aos fluxos do cosmos - mais precisamente, ao seu futuro. A vida, assim, envolve uma contínua alteração do corpo, cujo momento crítico é o começo da adolescência. Como veremos, tanto o xamanismo quanto a menstruação são eventos (afecções) que marcam o potencial não-orgânico e suplementar do corpo precisamente na época da puberdade e da formação de relações complementares baseadas na reprodução sexual e orgânica.

Para os Ikpeng, o xamanismo - mas não o xamã em si (que, como veremos, não existe em si) — tem algo de vil ou de feio (karake-bra). Certa vez, diante da minha infatigável insistência no assunto, Oporike - já um tanto incomodado com minhas questões - avisou-me de que eu iria me decepcionar com a realidade à minha volta, explicando que eu poderia acabar por enxergar o verdadeiro tecido social ikpeng que me embrulhava: um fluxo de "relações" (como reações vingativas), ensopado de raiva e inveja, configurado nas fugas noturnas do reflexo/sombra que atinge e mata os outros, um descontrole impessoal, que só o xamã percebe claramente com sua visão acentuada/morta. Avisou-me de que essa visão me assustaria tanto, a ponto de eu não mais querer voltar.

Seria melhor então não saber? Penso, na verdade, que Oporike subestimou (ou preferiu subestimar) minha capacidade de tolerar esse aspecto negativo porque - afora o fato de o xamanismo ser um assunto desagradável e um tanto perigoso - , normalmente, eu me dirigia mais a uma outra pessoa a fim de indagar sobre o tópico do xamanismo (Melobo, o xamã principal) do que a ele mesmo (Oporike sempre quis ser xamã, como seu pai, mas sua iniciação foi interrompida devido à guerra e à epidemia nos anos 50 e 60). Ele tinha também uma certa implicância com Melobo - e, portanto, comigo. Porém, como não podia proibir meu interesse, tentava dissuadir-me dele. Talvez houvesse um outro motivo: os Ikpeng tentam "(as)segurar" seus hóspedes (ou cativos), convencendo-os da vida serena e segura que vinga no seio da população. Mas, a seu ver, essa visão tranqüila é puramente ideológica, uma ilusão ou mentira (alo), e - ao contrário de algumas formulações recentes que pregam uma aparente tranqüilidade da "socialidade" 2 interior como pressuposto sociomoral na Amazônia (Overing e Passes 2000) — os Ikpeng sabem bem disso e não se confundem. São pragmáticos em dois sentidos: psicologicamente, porque supõem que os humanos agem por uma variedade de motivos, bons e ruins (para os outros); e filosoficamente, porque supõem, primeiro, que esses motivos e intenções pouco importam na determinação dos eventos concretos em que se envolvem, e segundo, que é muito provável que qualquer ação afete negativamente "alguém" - em um sentido não restrito à humanidade (recorte que a fenomenologia sempre procura fazer, em dire- 
ção contrária às indicações das cosmologias animistas que predominam na Amazônia indígena) (Overing e Passes 2000:7; Gow 1997). Para os Ikpeng, violar e estragar a vida dos outros (humanos ou não) é um aspecto inevitável da vida expansiva, que não tenta evitar contato com o mundo. Contato que implica sempre algum tipo de conflito, implícito ou não. Para eles, ignorar este fato é sempre um tanto infantil, para não dizer perigoso - isto porque suas ações sempre podem provocar a vingança alheia. Tudo pesa. A meu ver, uma ética inseparável do animismo.

Mas há um outro aspecto. O fluxo negativo e oculto de inveja, ressentimento e raiva dos outros tem uma dimensão sociopolítica altamente positiva, embora não explicitada pelos Ikpeng: sua constante ameaça inibe a acumulação e mantém o fluxo e a redistribuição de recursos mais ou menos equilibrados em uma população que evita tanto a coerção quanto o conflito interno, justamente para manter este interior intacto e liso - sem blocos internos, que seriam ipso facto já externos: cisões. Por outro lado, se nos colocarmos sob a perspectiva do outro - de um não-Ikpeng existe ainda uma outra versão positiva caso esse negativo (fratura do socius) fosse atualizado: é a possibilidade de se aliar a outra população ou outro povo (de novo: humano ou não) - regime político de autonomia, pacto e contínua realiança que Rivière (1984) descreve com acuidade nas Guianas, mas que no caso dos Ikpeng - como veremos a seguir - é expandida para além do universo social/humano.

Expansão que é ao mesmo tempo extensiva e intensiva (Viveiros de Castro 2000:21), ou, como apontamos acima, ainda corporal mas já nãoorgânica. Pensar essa condição não é tão difícil, mas como fazer o nãoorgânico? Este tópico é essencial para toda a discussão presente neste artigo, porque é o foco de todas as práticas rituais ikpeng. Veremos que ele coloca em questão a diferença entre pensar e agir, ou melhor, como atualizar sua não-diferença, idéia que para nós poderia definir a ilusão ou loucura, a falta de juízo, o erro, o sujeito perdido. Ao positivar essa perda, o sonho é seu modelo por excelência. Não por acaso, as atividades noturnas evocam um âmbito denso de implicações cosmológicas para os Ikpeng.

\section{No formigueiro}

O foco de atenção durante a maioria das estações secas é o Pomeri, seqüência ritual cujo ponto culminante é a "recaptura" e tatuagem das crianças - nativas, adotadas ou capturadas. As danças acontecem principalmente à noite, dentro e fora da maloca principal. Nas primeiras horas da 
madrugada, quando a maioria dos participantes cai no sono, restam apenas alguns flautistas e uns poucos dançadores, que continuam a circundar os postes centrais, realçados intermitentemente pelas pequenas chamas dos fogos - todos os homens têm seus rostos mascarados e carregam peles de animais nas costas. A impressão externa (deliberada) é a de formas quase-humanas, confundidas com espíritos animais por aqueles que começam a dormir ao redor. Entretanto, as máscaras de polpa de bambu têm outra função: elas cegam quase que por completo os dançadores (na verdade, as mulheres são totalmente cegadas, destinadas a depender de seus parceiros masculinos, que as guiam (ver foto 1). Assim, os dançadores tanto desorientam quanto confundem a si próprios. O efeito das máscaras é bidirecional: atinge usuários e espectadores.

Embora os rituais ikpeng variem muito entre si, é essa confusão humano-animal que domina. Ou melhor, essa dissolução. Na famosa resposta de Lévi-Strauss (1962) ao criticismo de Sartre quanto à pretensão de analisar os homens como se fossem formigas, ele aponta a complexidade social e técnica desses insetos; em seguida, anuncia sua visão de que, de toda forma, o objetivo último das ciências humanas seria não o de constituir, mas dissolver a humanidade.

Curiosamente, isso encontra eco afirmativo entre os Ikpeng. Seu nome "ikpeng" refere-se a um filo híbrido de formigas e vespas ${ }^{3}$, o que implica uma autoconcepção bastante complexa. As pessoas comparam a fase-formiga (arayo) de coleta e feitura de ninho no solo à sua própria produção de roças e malocas; enquanto a fase-vespa (turum), associada ao nomadismo guerreiro e à caça coletiva, alterna entre o enxame predatório e o ninho arbóreo ao que corresponde uma alternância ikpeng entre os ataques mesmos e a base nos acampamentos, quer se trate da guerra ou da caça (há algum tempo a guerra foi descontinuada, mas permanece latente a ameaça de sua reemergência). Por isso, trata-se menos de uma autodesignação do que de uma auto-apelidação - uma descrição etológica daquilo que a população circunscrita apenas precariamente como um "nós-exclusivo" (tšimna) seria capaz. O hibridismo do nome indica um conjunto modal - um povo no modo povo. Aliás, vários modos exclusivos (não-totalizados), cada qual um desvio provisório, produtivo, comunicativo, disperso e quase imperceptível, como os movimentos cíclicos dos insetos.

Ao contrário do pensamento humanista e suas tentativas de destilar e conservar sua própria essência, os Ikpeng mostram vivamente em seus rituais os modos através dos quais instilam a si mesmos como um povo, sempre em uma mistura impura de elementos dissolvidos. Seu autônimo 


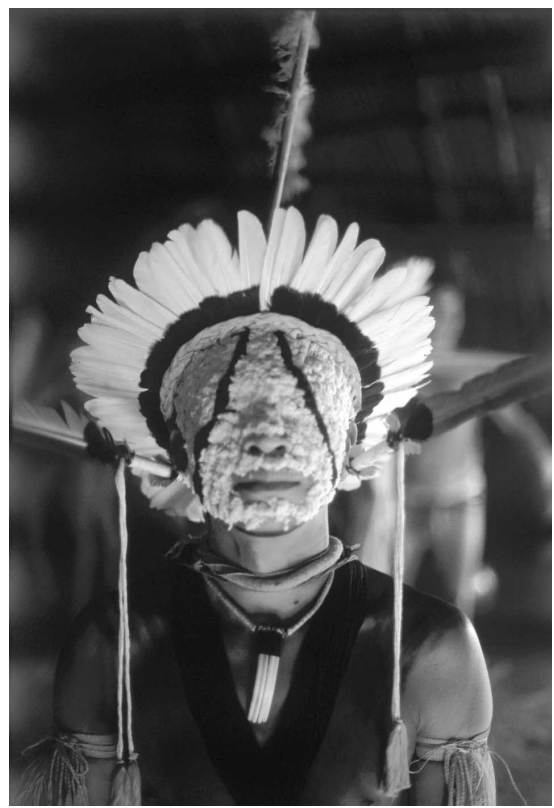

1 Korotowi esperando o pôr-do-sol e o início das músicas. A camada de polpa de bambu (com desenho de sucuri) recentemente aplicada já está quase seca. Depois, ele poderá abrir um pouco os olhos, apenas o suficiente para enxergar o caminho da dança; sua parceira permanecerá cegada pela máscara até o amanhecer do dia seguinte.

não é, portanto, apenas simbólico: antes, os Ikpeng projetam-se via um nome-diagrama que compõe explicitamente suas qualidades guerreiras, como rapidez, invisibilidade, agressão e inexorável proliferação (ao menos no tempo cósmico), focalizado na "picada" - a cúspide no duplo sentido, ferrão e ponto de coincidência — da matança de adultos e/ou rapto de crianças que soma como ponto crítico da identidade ikpeng. Isto é, a inversão (ou não) do afluxo negativo marcado pela morte de um Ikpeng - cuja fonte é sempre exterior - que, por um intervalo de luta a ser depois suprimido, provocou a busca de vingança. A reação vira pró-ação - e, assim, provocação, incentivando os inimigos a procurar sua própria vingança. Este ponto é configurado na atuação do líder de guerra, homem chamado urotšum: urot+yum, "inimigo+anômalo".

Voltaremos depois a esse tema. O conjunto formiga-vespa é, de fato, um tema ritual comum entre outros povos caribe, inclusive entre os Arara (Teixeira-Pinto 1997:161-162), onde esses insetos são utilizados para picar os jovens durante a iniciação. Jara (1996) faz um estudo detalhado de seu uso entre os Akuriyó como um prelúdio à caça masculina e à menstruação feminina no início da fertilidade, que traz o duplo influxo de corpos novos - animais de caça e crianças - e a simultânea e perigosa liberação ou refluxo de sangue: animal e menstrual. Mas por que usar esses insetos? O fator comum essencial parece envolver múltiplas picadas, que levam o 
noviço à beira da intolerância física e mental: elas agem como muitas pequenas mortes ${ }^{4}$. Um tipo, pois, muito particular de morte: múltipla e molecular. Os Ikpeng atualizam uma outra versão do uso desses insetos, esfregando o carvão derivado da queima dos vespeiros em cortes nas pernas e braços de meninos a fim de torná-los fortes, rápidos, resistentes e agressivos. Assim, ficam prontos para a guerra. No lugar do artefato tecido (ou ninho substituto) cheio de insetos vivos utilizado por outros povos caribe, os Ikpeng usam ninhos das próprias vespas, os quais são efetivamente submetidos a um processo post mortem (queima) que termina com a aplicação de vespas mortas-ausentes ${ }^{5}$.

A separação das modalidades formiga e vespa atua de forma profunda na cultura ikpeng - uma clivagem personificada por duas figuras que agem como pólos de oposição, a saber: o líder da maloca e o líder de guerra. Estas posições são estritamente incompatíveis: não podem ser assumidas pela mesma pessoa. Ao mesmo tempo, certos parâmetros sociais indispensáveis para os Ikpeng, como igualdade e autonomia pessoal, implicam que qualquer homem é um ocupante em potencial dessas posições, seja através do ato de fundar uma maloca ou aldeia e comportar-se como seu ápex social, seja agindo como o estímulo e o foco organizacional de uma expedição de guerra. Isso se aplica igualmente aos líderes rituais (inclusive aos patrocinadores dos rituais de iniciação do Pomeri, continuamente em substituição) e aos xamãs. Portanto, o plano sociopolítico ikpeng combina equivalência e incompatibilidade, o que reflete a lógica da substituição difundida em seu pensamento cosmológico, onde posições, agências, subjetividades são continuamente substituídas e renovadas alhures e por outros. Trata-se, essencialmente, de um ethos nomádico, que - como veremos adiante - concebe a modelagem arquitetural (a configuração maloca/líder) como um modo particular, não totalizante.

\section{Intoxicação como autoviolência}

Para os Ikpeng, o foco do mundo é a floresta, e seu modo de exploração a caça e a guerra. A densidade da floresta assume um contorno particular: um conjunto eternamente variável de contextos (em ikpeng etšit-kom, os territórios das espécies silvestres e aquáticas) que se sobrepõem, produzindo uma gama de combinações compatíveis (simbióticas/afins) e incompatíveis (predatórias/tóxicas/hostis). Os territórios dessas espécies se definem menos por seus abrigos, ewrṫ(maloca, ninho, bolsa), do que por sua expressividade - derivada de cheiros, cores e sons. Os aromas são cru- 
ciais para determinar a compatibilidade das espécies, suas zonas de coabitação, os ritmos sazonais de sua fruição, mutação e declínio, e assim por diante. Os humanos são, por sua vez, também inseridos no mundo da floresta segundo linhas particulares de "comunicação sensível". Portanto, a aproximação é tudo: conquanto seja feita com tato de caçador. A floresta densa é chamada iruwa, designando "o lugar dos gritos", nome que focaliza os sons e as espécies, não o habitat; as línguas selvagens (iru), não a aparentemente infinita extensão de árvores. A caça envolve uma abertura para outras vozes, uma acústica diferente. Seja usando armadilhas ou armas, ela implica uma antecipação das ações das presas animais e uma posterior subversão dessas ações. Em ambos os métodos, artifícios sedutores são também empregados: utilizam-se iscas visuais e aromáticas (comida), no caso das armadilhas, e no caso da caça com armas, atraemse pássaros e animais em geral através da imitação de chamados das espécies $(i r u k u)^{6}$. Portanto, se, por um lado, há um grande investimento em modos de pensar alheios, por outro, este se funda no engano e na violência. Os homens ikpeng encantam-se com esse perigo. Mas se a floresta é um destino diurno, ela é também um destino genérico, no sentido profundo: os Ikpeng estão inexoravelmente atados a ela como sua fonte de morte e vida. Até o momento, a despeito da ameaça sedutora do capitalismo, não há alternativa: a vida precisa ser extraída de seu tecido intricado, sua fauna abatida, suas fileiras de árvores reduzidas a cinzas para a abertura de roças, ou arrancadas da terra e deformadas para a construção de malocas. Tal violência - uma verdadeira arquiviolência - provoca a ira incansável dos aflitos (todas as outras espécies), ira que deve ser tratada com astúcia pelos Ikpeng sob pena de submissão e perecimento. Contrastando com essa ira provocada (uma negatividade sempre deixada para trás que toma a forma de wonkinom/espíritos-demônios), a violência ikpeng é a priori pró-ativa - e, assim, vívida, não mórbida.

Portanto, os Ikpeng assumem sua própria trilha através do mundo como algo inevitavelmente destrutivo. Esse reconhecimento é válido tanto em termos etológicos quanto éticos: ele mapeia o fluxo dos corpos/ substâncias no cosmos e sela seu próprio destino. As espécies afligidas vingam-se sob a forma de doenças (causadas por ataques de minúsculas flechas), culminando com a morte e o consumo canibal dos recém-falecidos pelos habitantes celestes - já mortos. Mas já que não há como escapar desse retorno, os Ikpeng procuram absorvê-lo. Cria-se uma certa tecnologia aberrante: diante de sua condição precária e transitória, a cultura ikpeng pressupõe e opera continuamente com o efeito vital do tóxico, isto é, pressupõe sua composição "alógena" ou "alopoiética" onde o futuro or- 
gânico (humano) depende do influxo parcial e não-orgânico de outras espécies, outros povos, outros modos. Sujeitos parciais - em ikpeng, egt, cativos/animais-domesticados/flautas (ver Fausto 2001). Essa dependência requer uma absorção corporal que altera o eu/nós (o povo ikpeng) através de uma expansão da "afetabilidade" (a capacidade de ser afetado por novos elementos) que sempre traz embutido o risco de morte.

Tal intoxicação - tipicamente alcançada na Amazônia através de substâncias alucinógenas/psicotrópicas, de bebidas fermentadas e também do desequilíbrio somático provocado por dança/música intensas pode ser vista como uma autoviolência positivada. Essa composição de fatores compromete fatalmente, penso eu, a proposição das teorias mais fenomenológicas da etnologia amazônica de que os rituais alteram o outro, mas não o eu, baseada em sua tendência a recalcar a violência como se fora o mal puro (Overing e Passes 2000:7). Essa conservação do humano e da auto-identidade faria pouco sentido para os Ikpeng: sua condição de vida depende da sobrevivência a - e não da evitação de - encontros potencialmente danosos ou letais com outros corpos, pessoas e substâncias. Exemplos de auto-intoxicação ikpeng incluem o consumo de wonkinom-egrt (bebida-dos-espíritos), uma densa cerveja de milho e mandioca feita ocasionalmente durante os rituais de inverno, tomada apenas pelas pessoas mais maduras, que "morrem" na ocasião. Fonte vital (crescimento e potencialização) extraída de uma morte sobrevivida, wonkinom-egrt é uma poção que atrai os espíritos, que, entretanto, podem estragá-la caso os xamãs não os impeçam de bebê-la, e cuja implicação mais drástica seria a morte da população inteira. Esta aproximação e visitação de vida alheia como uma morte episódica interrompe a vida ikpeng, de modo que a freqüência das mortes e a resistência a elas aumentam com a maturidade, o que explica tanto o fato de haver um temor pela população como um todo, quanto justifica o risco da provocação deliberada aos espíritos, que, no limite, podem aniquilar essa população e atualizar uma forma nãosobrevivida de morte (não mais fonte vital).

\section{A morte (entre parênteses)}

Porque nenhuma razão me compele a sustentar que o corpo só morre quando se transforma em um cadáver (Spinoza, Ética, IV P39 Escol.).

Seria a morte igual para todos? Apesar de este ser um assunto prontamente evitado pelos Ikpeng (falar o nome dos mortos implica evocá-los, 
e portanto convocá-los), a morte intercalada na vida suscita um interesse especial. Particularmente à luz do dia. E foi assim, certa tarde, com o sol ainda em cima da maloca e das copas da floresta por perto, enquanto eu anotava um mito sobre a guerra, que Awato (o jovem que mais me ajudou nas traduções e transcrições em geral) me perguntou, subitamente, se os não-índios (tupi) morrem apenas uma vez ou se morrem muitas vezes como os Ikpeng. Fiquei calado por alguns momentos, pois qualquer resposta a essa questão me parecia fútil, já que, a meu ver, Awato previra exatamente o que eu iria pensar e também o que eu não iria pensar. Qual foi o ponto, pois, de sua questão? Hoje sei o quanto me equivoquei naquele momento: Awato não estava sondando o possível compartilhamento de uma crença (um conceito de valor muito limitado para os Ikpeng), mas a possibilidade de sustentar a morte múltipla.

Sem dúvida, é esse traço sutil e algo tácito de positivação da morte (de si) que faz a diferença. Tais mortes são extremamente freqüentes. Morre-se (irompo) durante pesadelos, desmaios, febres agudas, intensa atividade de dança e canto, convulsões epiléticas, tonteiras causadas por grande perda de sangue, embriaguez e transe xamânico. Todos esses eventos envolvem estados de intoxicação/tongnore que sacodem a pessoa aflita, provocando alternância entre um estado inerte ou comatoso e uma disfunção trêmula dos músculos - uma desorganização do corpo, acompanhada sempre por certos tipos de distúrbios visuais, tratados quando necessário ou possível com uma espécie de colírio nativo feito de extrato de wonkinom-eretput/cabelo-de-demônio, que redesperta o aflito. Nestes paroxismos, um corpo não-orgânico é produzido: o funcionamento tipicamente orgânico do corpo é suspenso, enquanto o aspecto que escapa ao corpo - a alma/sombra/reflexo/eco (egaron-ptn: visitante+ex) - migra e se torna ele mesmo exposto a espíritos hostis. Assim, a doença consiste em uma perda incipiente da alma/reflexo e sua captura por espíritos demoníacos, enquanto o xamã morre em cada sessão de cura ou vidência, quando sua alma (aumentada com seus espíritos auxiliares) procura e recaptura a alma capturada de seu paciente, empurrando temporariamente esta última de volta ao mundo diurno; o sono inevitavelmente provoca o sonho, um vagar da alma no mundo de espíritos demoníacos; experiências noturnas que agem como presságio de um futuro potencial - antecipações menores de eventos na morte final. 


\section{Afetos e devires}

Esse mundo demoníaco, no entanto, é também nosso. O cuspe do xamã no chão é um vasto e impenetrável lago para espíritos; uma tocha acesa em suas mãos é um incêndio devastador na floresta; a orelha-de-pau é o beiju dos mortos. Trata-se da expansão e potencialização de detalhes aparentemente incidentais do nosso mundo, um processo de redimensionar o plano molecular ao plano cósmico, que vai ao encontro das iluminadoras análises das sociocosmologias amazônicas recentemente formuladas sob a noção de perspectivismo por Lima (1996) e Viveiros de Castro (1996). O tempo-espaço dessas múltiplas e antagônicas possibilidades é idêntico. Assim, em um sentido estrito, há de fato apenas um mundo; o que difere são as fontes (ou pontos) de avaliação dentro do mesmo. Esses pontos não são mentes nem corpos, mas - como propõe Viveiros de Castro (1996: 128) - as permutações e combinações de comportamentos e afecções delineando um animal ou outro ser, as quais poderiam ser visualizadas como o compósito ou desenho de uma espécie: um contorno de vida (natural ou sobrenatural).

Esse nível de abstração se faz necessário para que evitemos confusões causadas pela projeção de nossas próprias assunções naturalistas e essencialistas nas idéias amazônicas, e as tratemos, por conseguinte, como irreais (ou simbólicas, metafóricas, imaginárias etc.). Tais projeções sem dúvida obscurecem uma avaliação do mundo que é muito mais sutil, baseada no mapeamento do trânsito contínuo de comportamentos, movimentos e afetos entre os corpos-espécies, à qual corresponde uma "lógica do sensível" que reduz a taxonomia a uma base indicativa para extrapolar as variações e permutações, em vez de nossa expansão da taxonomia em uma aproximação cada vez mais aguda e restrita de seqüências genéticas em suas instâncias concretas.

O potencial de expandir os pontos mínimos ou obscuros do mundo é um traço marcante do pensamento cosmológico ikpeng — os seres pequenos (tšikap), tais como o beija-flor, o esquilo, as abelhas ou vários peixes menores, sendo os mais potentes: todos xamânicos/ptat-pe. Essa idéia fica clara no mito ikpeng sobre a origem proto-humana dos animais. Certo dia, o morcego ludibria sua sogra arraia no interior da floresta, onde fixa uma armadilha para peixe em um córrego. Durante a noite, a armadilha captura os gritos de todos os futuros animais. Esses gritos aterrorizantes mantêm a arraia em vigília por toda a noite, até que o dia amanhece e, exausta, ela acaba por adormecer. O morcego, então, corta sua vulva, cheirando-a euforicamente (está alegre, embora esteja sozinho, enfatiza o nar- 
rador), e retorna à aldeia. Lá, o sangue da vulva da arraia é misturado com uma tinta pelo sauá (macaco Callicebus) e aplicado naqueles que estão na fila de espera dos futuros animais. Cada um que vai sendo pintado adquire seu desenho, cheiro, fezes, som e comportamento distintivo ${ }^{7}$ - seus códigos expressivos - , e logo some para a sua respectiva região e patamar da floresta.

A euforia do morcego cego e noturno sozinho na floresta antecipa, dessa forma, a chegada iminente de outras populações (o que nos remete aos dançadores ikpeng no ritual Pomeri: mascarados e cegados): essas espécies/povos novos são catalisados - em ikpeng, oruku, autodesenhados/autocontornados - pelo sangue genital-menstrual da arraia.

Aqui, o vetor humano $\rightarrow$ animal está seguramente (para nós) confinado no passado mítico (ver Hirtzel 1997). Mas o que fazer dessas pessoasvirando-animais na atualidade descritas pelos Ikpeng: xamãs, dançadores, aflitos? Usualmente, a etnologia explica essas asserções indígenas como simbólicas ou metafóricas. Indubitavelmente, esse viés deriva das premissas humanistas da antropologia que sustentam um imperativo moral subjacente para o reconhecimento do humano. Mas penso que isso é profundamente errôneo no que diz respeito aos tipos de afirmação (verbais ou não) que esses povos fazem sobre o mundo. Para tomar o exemplo clássico da região, os xamãs são comumente descritos pelos indígenas amazônicos - inclusive pelos Ikpeng — como virando onças (também outras espécies) no momento do transe. Reichel-Dolmatoff toca parcialmente nesse tópico quando se pergunta: “A questão é: até que ponto pode um homem se tornar onça? Um pajé-tornado-onça é, para todos os propósitos exteriores, uma verdadeira onça: ele tem a voz de uma onça, ele devora carne crua, ele dorme no chão, e ele tem os sentidos visual e olfativo altamente desenvolvidos do felino" (1975:132, ênfases minhas).

Os Ikpeng usam o verbo $u k u$ para apontar esse tipo de devir-animal. Mas como definir o tipo de evento atribuído a esse verbo? Não se trata nem de imitação (se fosse o caso, o uso maciço de tabaco pelos Ikpeng bem como o uso difundido de drogas psicotrópicas entre outros povos amazônicos inibiriam, mais do que auxiliariam, o ator — afinal de contas, o xamã freqüentemente cai inconsciente), nem de uma imputação de que o xamã de alguma forma se transforma "realmente" em uma onça, em quem pêlos e bigodes cresceriam, já que a evidência sensorial dos que o circundam indica palpavelmente o contrário. Então, como se pode entender esse devir-onça, que é ao mesmo tempo não-simbólico e não-real (ver adiante para uma redefinição ikpeng do real)? Temos de deslocar nossa noção de "onça de verdade" - a qual, para muitos ameríndios, pode até não ter 
nada de onça, particularmente se ela age de forma estranha, de modo incomum, não-onça de ser (pode muito bem ser um espírito ou um outro xamã humano) - e nos focarmos nos traços indicativos e expressivos das onças, seu contorno-espécie. Nesse caso, chegamos a um comportamento ou etologia "tipo-onça" - que pode (ou não) ser atingido tanto pela onça quanto pelo xamã. Isso é completamente "razoável" ou "realístico", no nosso sentido - não demanda nenhuma suposição de ilusão ou mau reconhecimento da parte dos ameríndios, mas um reconhecimento de nossa parte que uma afirmação de ordem diferente sobre a realidade está sendo feita (e não uma afirmação para uma realidade de ordem diferente, como supõe o relativismo; ver Overing 1990 para um exemplo das complicações sem saída dessa posição). Não-dogmáticos, os povos amazônicos são talvez bem mais céticos quando se trata de percepção do que nós mesmos. O real é sempre difícil de ser avaliado. Daí a ênfase em uma contínua enunciação, denominada "mítica" por nós mesmos, das possibilidades cósmicas através da fala ausente dos animais e outros seres ${ }^{8}$, em vez de uma idealização da forma presente como identidade, verdade e autenticidade (base de sustentação de toda fenomenologia ${ }^{9}$ ).

Penso que essas idéias podem ser mais bem exploradas através da noção de afeto, tal como formulada na filosofia de Spinoza e mais recentemente por Deleuze e Guattari (1980). Aqui, os afetos não são simplesmente sentimentos ou emoções, mas descrevem o que poderíamos chamar de redistribuição dos focos de densidade e sensibilidade do corpo, aumentando ou decrescendo seu potencial para agir de modo específico. Tais afetos são marcados na linguagem ikpeng pelo sufixo $p e^{10}$. Por exemplo, zangado/wonkin-pe pode ser traduzido como afeto-demônio ou afetopredador. Esses adjetivos não descrevem nem uma possessão por uma força ou substância exterior nem uma correlação metafórica, mas uma afecção: uma espécie de ressonância comportamental contagiosa. Enquanto a exposição ao que é externo é invariavelmente "singular" e "subjetiva" (o reflexo/sombra da pessoa isolada, no sonho ou na mata, é primeiro afetado, depois, seu corpo/carne), o agente afetante é invariavelmente múltiplo. O sujeito ikpeng afetado começa a entrar em uma mescla populacional, se somando a esta, suplementando um povoamento heterogêneo e, por enquanto, indeterminável em qualquer sentido afixado ou absoluto.

O que será esse aspecto exposto? Penso que o reflexo - o "princípio vital/alma" sem o qual a pessoa morre (isto é, começa a morrer) - funciona como a possibilidade de singularização e, portanto, a possibilidade e liberdade de morrer. (Aliás, a antiga descoberta da morte foi um alívio para os ancestrais dos Ikpeng, exaustos com o perpétuo retorno dos mesmos 
nunca-mortos.) Ele constituiria um princípio mortal, negativo e feio, aquele que marca uma ausência potencial ou atual como perda e fuga, uma morte-em-processo: daí sua atualização como sombras, reflexos e ecos. No entanto, quando é ativamente bloqueada pela volição humana/ikpeng, essa morte-em-processo não é a súbita e passiva aparente substancialização ${ }^{11}$, produzindo o corpo-como-carne, o cadáver - o indivíduo em toda a sua desolação - , mas uma dissolução do estado afetivo do corpo e sua resolução temporária em outras combinações afetivas - uma perda de identidade pessoal em um "devir-múltiplo", exprimido pelos Ikpeng pelo termo $u k u$ : pois este envolve sempre um "toque de maldade". A eventual liberação dessa fuga bloqueada recebe uma outra variação verbal: aluku. O termo aplica-se quer a alguém que não volta da floresta, quer a um animal sendo perseguido por um caçador - o qual subitamente altera seu formato para uma aparência embaçada de uma outra criatura, estranha e logo sumida. Tais eventos são reportados bastante freqüentemente pelos Ikpeng, somando como que o excesso da caça, quando uma presa é atingida pelo caçador mas ainda assim some. Eles implicam uma morte por ausência, sem cadáver, que pode ser literalmente traduzida como um "devir-mentira" ou "devir-erro", alo+uku: uma forma errante em todos os sentidos. O termo resume sucintamente um aspecto crucial do pensamento ikpeng, a saber: o de que o "errado" ou "falso" não é irreal, mas simplesmente incompatível com a afirmação humana/ikpeng do mundo ${ }^{12}$. Tensão ontológica revelada na fórmula usada pelos Ikpeng para delimitar aqueles exemplos de animais que nós tentaríamos definir como reais: alukuṫgemnt, "ele não some/sumiu (ainda)". Nossa comida.

Devir/sumir não é transformação, já que não ocorre ainda nenhuma passagem para uma nova morfologia claramente definida. De fato, a identificação da nova forma de uma pessoa aflita, sumida ou morta é sempre retrospectiva e feita somente pelo xamã nas suas sessões. A transformação - transição de uma forma/espécie para outra - é chamada inukunkanum. Outro conceito, portanto ${ }^{13}$. A diferenciação teórica entre transformação e devir (Deleuze e Guattari 1980, cap. 10) parece-me imprescindível para uma análise coerente dos conceitos ikpeng que vêm a tona na presente discussão. É habitual chamar as culturas amazônicas de "transformativas" - proposição verdadeira mas redundante, aplicável às mudanças histórico-temporais de qualquer cultura - , por conta de sua fluidez sociocosmológica, evidente sobretudo nas mitologias. Como penso ter demonstrado acima (bem como mais abaixo), as noções indígenas são muito mais complexas, matizadas e nuançadas do que as nossas; daí a necessidade de buscar recursos em outras áreas. Para os Ikpeng, por exemplo, 
o conjunto dessas noções opera através de uma sondagem e calibração de intensidade cosmológica - o potencial alheio de todo ser — que surge atualizada sempre como o já é ou já era (dependendo do momento da avaliação): o queixada com aspecto humano no mito já era animal (pós-humano), o xamã já é animal (pós-humano), o doente já é morto (pós-humano).

Esse fluxo temporal - em geral apreendido por nós ao inverso, como um fatalismo a posteriori - me parece intrínseco a uma avaliação diferida do mundo, a qual imputa valor ao resultado da ação e não à sua origem ou intenção14. Calibrar, testar, provar, experimentar, imitar, desenhar, sondar: o verbo $u k u$ traduz todos esses conceitos e nenhum deles. Afeto (ou devir) permanece inevitavelmente para nós uma idéia bastante estranha e elusiva, pois nossa tendência é pensar ponto a ponto, forma a forma, e assim pensar e cristalizar os afetos como meros movimentos transitórios: como transformações. Os afetos - acionando partículas mistas mas sempre acopladas a um tipo: afeto-abelha, devir-queixada, afeto-inimigo são vetores em si, que abrem, sempre, para a potencial vinda do novo. Como veremos agora, por isso, os eventos da puberdade têm uma ressonância particular, especificamente a primeira menstruação e a iniciação xamânica. Examiná-las requer em primeiro lugar um breve desvio pela cosmologia ikpeng.

\section{Sob o efeito do trovão}

A primeira vez que visitei os Ikpeng foi em setembro, no começo da estação chuvosa, quando as tempestades passam a ser freqüentes, o que me propiciou uma imersão abrupta na cosmologia ikpeng, já que as tempestades elétricas acompanham a visitação de Imere — um deus solitário (mas nada primordial), enfurecido pelo derramamento de sangue menstrual nos rios, que busca vingança para a morte de sua mãe, assassinada por seu pai (Anpanta), supostamente ikpeng. Seu mito conta que Anpanta, por sua vez, estaria enfurecido pelo desejo excessivo de seu filho Imere de obter mel, que conta com a complacência de sua esposa (a mãe de Imere). Assim, Anpanta resolve ludibriar sua mulher Maru: quando esta sobe uma escada para extrair mel no buraco de uma árvore, Anpanta retira a escada, deixando-a com o braço preso no local. O braço quebra-se e o marido a abandona pendurada na árvore para que morra. Logo após esse ato, ele grita para sua mulher: "vire abelha! vire qualquer coisa!", e depois abandona o pequeno Imere sozinho na floresta. O espírito da mãe diz ao menino que ele deve procurar seus avós maternos na floresta. Ele então inicia 
sua jornada épica, encontrando uma seqüência de abelhas, vespas, marimbondos, escorpiões e centopéias: a cada encontro um dos bichos o pica até a morte e o ressuscita na manhã seguinte, e assim sucessivamente. À medida que Imere cresce e se fortalece após cada uma das mortes, as espécies vão se tornando mais duras e perigosas, até que finalmente ele encontra um poraquê, que lhe explica que agora, já grande, Imere tem de morrer de vez. Ele aceita seu auto-sacrifício e o poraquê constrói um jirau e coloca Imere em cima. A esposa do poraquê bate nele com um bastão de pilar, como se estivesse amassando milho, mas a madeira do jirau abaixo de seu corpo se quebra. Imere sobrevive. Após inúmeras tentativas, o casal encontra uma árvore forte bastante para sutentá-lo e Imere é finalmente morto. Ciente da sua nova potência, ele atinge rapidamente o céu. Assim, ele se torna o primeiro xamã. A segunda seqüência do mito descreve seu retorno à terra e sua vingança contra Anpanta e seu povo: decide seduzir a nova esposa do pai, o que provoca a tentativa fracassada deste último de moqueá-lo (pois Imere convoca as primeiras chuvas fortes para extinguir o fogo), e culmina com Imere matando seu pai e a maioria de seus parentes paternos na explosão do primeiro raio (que incidentalmente cria a primeira roça). Finalmente, ele parte para o céu, amaldiçoando a humanidade que restou, jurando-lhe de morte, e carregando consigo seu imenso conhecimento tecnológico, além de inúmeras criaturas celestiais e o próprio rio Amazonas em sua trilha, alcançando o céu onde este toca hoje a terra, no extremo leste. Em seu caminho, ele distribui as várias tecnologias para os inimigos dos Ikpeng, especialmente os tupi - ou nãoíndios. Já no céu, Imere mantém-se imortal através de uma auto-rejuvenescência, alcançada no processo de troca de pele como as cobras.

Cá na floresta, sob um céu periodicamente "escandaloso", os Ikpeng dizem que Imere está bêbado e insensato sob o efeito do sangue dos pais, e que sua mãe era na verdade ikpeng — o que nos remete à relação de afiliação mencionada acima com as formigas e vespas, já que estas surgem como seus avós maternos (inutptam) - , enquanto seu pai era um inimigo desconhecido. Tal ambivalência é intrínseca ao dobramento reflexivo da vingança/provocação presente na guerra ikpeng. Porém, cabe notar aqui que uma gênese das intenções seria de pouco valor para os Ikpeng. As conseqüências eventuais permaneceriam as mesmas: o eterno e sazonal retorno vingativo de Imere. Quando ele se aproxima, as tempestades são repelidas pelos mais velhos, que extinguem os fogos, cantam versos que ridicularizam a "visitinha de Imere", com risos indolentes, e tocam flautas de guerra - que no passado eram feitas de ossos humanos (agora feitas de ossos de onças). Enraivecido pelos sinais do cozimento dos ani- 
mais deixados pelos Ikpeng — fogo e sangue — Imere ameaça-os com duas catástrofes: um dilúvio feito de chuva ruim e espíritos de macacos (a presa ritual) ou um choque de raio diretamente nas malocas. Mas a chegada de Imere, dono-das-águas, durante as tempestades também deixa o mundo imediato imere-pe: "afetado-por-Imere". Esse afeto é fortemente sentido, de forma particular, por dois conjuntos de pessoas: xamãs (que são quase sempre homens) e mulheres no período de menstruação.

\section{A menina diluída}

A reclusão das meninas durante seu primeiro período de menstruação tem dois propósitos explícitos: um é purgativo, possibilitando seu crescimento; o outro inoculativo, prevenindo-as de tonteiras (tongnore) durante as tempestades. Antes do amanhecer do dia seguinte aos seus primeiros mênstruos, um xamã (idealmente seu avô paterno) procura as plantas medicinais ( $\not u g u)$ que ela deverá ingerir — vários tipos de cipó, que são amassados e misturados com água. A menina deve beber essa poção até que vomite. Depois bebe de novo — dessa vez "a enchendo até o topo de sua cabeça" - até que vomite uma vez mais. Essa purgação é repetida a cada manhã, meio-dia, e noite até a sua próxima menstruação. Durante esse tempo, ela permanece em reclusão em sua casa, suspensa em uma rede atrás de uma tela improvisada com folha de palmeira, consumindo apenas $t \dot{t g} r i u$, um mingau feito de beiju ensopado. O peixe, especialmente, deve ser evitado, bem como qualquer alimento quente, doce ou gorduroso, incluindo pimenta, carnes e mel. A menina também deve abster-se de sexo, sob o risco de não poder andar propriamente depois. As bebidas pugu e as várias restrições alimentares contribuem para um aumento da força e da massa corporal.

Quando o sangramento parar, ela pode voltar a comer comidas leves, tais como pombos e jaós. Uma planta chamada tupala - ou imere-apon/ borduna-de-Imere - é coletada dos córregos, onde vinga, depois secada ao sol e, finalmente, queimada, para que o carvão seja aplicado sobre o seu corpo. Isto serve para prevenir as tonteiras e os gemidos incontroláveis quando chega a tempestade (um comportamento típico dos mortos, moradores celestes, durante os eclipses). Também se pode aplicar um remédio para os olhos para dissipar náuseas ou pesadelos: é feito de folhas - imere-enptiṫ/gotas-de-Imere ou komoperatput/pêlo-de-centopéia - e deve ser esfregado e espremido em uma solução com um pouco d'água e pingado nos olhos da pessoa afetada. 
O fluxo menstrual é definido com uma expulsão de sêmen podre, efetivamente um aborto, quando o sêmen (imu) não chegou a coagular para dar início à formação do feto. (A maioria dos adultos mais velhos diz que a criança é formada inteiramente pelo sêmen, embora algumas mulheres jovens, como Agiwo, se mostrem um pouco céticas no que diz respeito a essa idéia.) Essa descarga de imu putrefato tem um efeito negativo em todas as substâncias alimentares ikpeng: um lote inteiro de pasta de mandioca processada (imnu/carne/polpa) pode ser descartado - sempre discretamente jogado atrás da casa - caso uma das meninas ou mulheres envolvidas em sua preparação descubra que ficou menstruada (moria-pe). Também as chances de um marido ou amante que esteja pescando ou caçando diminuem drasticamente, já que o odor contaminante de sangue alerta e afugenta a presa (efeito que também se aplica ao nascimento e aos primeiros dias após este, quando a caça e a pesca são evitadas).

Apreendida como vetor, a menstruação é um processo diametralmente inverso ao crescimento fetal e corporal atingido através da produção feminina de alimentos vegetais e da predação masculina de peixes e caça um desfazer, uma saída de fluxo altamente perigosa que faz apodrecer a comida, afugenta a presa, mas enraivece e atrai Imere, estimulando seu desejo pela mulher menstruada, uma demanda cuja atualização seria sua morte. A toxicidade dessa reversão do processo de "fazer filho" também causa distúrbios no pensar da mulher ( $\mathrm{e}$, por contágio, também no de seu marido e amantes), infectando sua visão com imagens oníricas - inteiramente reais (não-fantásticas), mas de origem alienígena e efeito alienante.

A menstruação é marcada como vergonhosa, pṫmne. Mas o que significa exatamente tal vergonha? A menstruação resulta da falha de uma interioridade em coalescer - assim ela provoca uma condição hostil para com os parentes e para com o socius de maneira geral. Na condição de forma de hostilidade, ela se equipara ao incesto, à epilepsia e à exposição dos afins através do uso direto dos nomes: ações e comportamentos igualmente ptmne. Nesse caso, a vergonha não é a expressão de uma resposta moral internalizada à exposição social de uma anti-social/má intenção, ação ou condição interna; ao contrário, o "rosto corado" marca o isolamento súbito e a raiva implícita das faces-avermelhadas decorrentes da exposição do socius como um produto artificial, fabricado ou "afinado": uma coagulação homem-mais-mulher que pode ser sempre violentamente desfeita. Seria um erro, portanto, interpretar essa vergonha como o resultado de uma resposta emocional, uma reação suplementar (supérflua ou histérica) a um evento; trata-se mais do inverso: a menstruação surge na vida da menina como um evento suplementar no seu corpo, afluxo 
invito e desintencional, depois do que ela nunca mais vai ser a mesma (que o menino). Faz-se o corpo feminino — produto das primeiras relações sexuais - com um desvio ou estrago (do sêmen/feto). Portanto, este evento cliva os sexos no eixo social equilibrado e orgânico (compondo o casal e núcleo doméstico), mas também no eixo cósmico desequilibrado e nãoorgânico (compondo outras alianças, outras contaminações, outros povos - como o sangue da arraia). A diferença sexual configura a diferença entre o socius e o cosmos (não como espaços, mas modos). Por isso, a menstruação não é nem causa nem efeito, mas um afeto aliando a menina/mulher temporariamente com o exterior. Assim, os períodos menstruais não são concebidos pelos Ikpeng como naturais, mas como selvagens ou errantes. A solução ikpeng para essa recorrente expulsão de hostilidade é, ao mesmo tempo, neutralizar e conter sua mistura de isolamento e exposição vulnerável. Enchimento, diluição e esvaziamento do corpo da mulher com um fluxo de bebida pugu produz um corpo vazio e neutralizado: envolvido e efetivamente encapsulado pelos parentes e por uma arquitetura doméstica - um novo corpo como espaço oco (definido pelo seu exterior abrigador, sua contenção).

Tal condição é idêntica à iniciação xamânica com meninos (e à reclusão do matador, tópico que não posso abordar aqui), exceto que o xamã futuro é contido pelo fluxo de forças exteriores: espíritos de outras espécies. Ainda que nunca seja explicitado pelos Ikpeng (até onde eu sei), o processo periódico e rítmico de jogar o corpo da mulher em "modo reverso", tributário de um doloroso e violento desfazer, implica uma proximidade feminina genérica com os xamãs. Mulheres são efetivamente xamanizadas pelos processos radicais da menstruação e do nascimento expostas a perigos, desmaios e visões intensas causadas pela perda de sangue e por um esvaziamento do seu interior: fisicamente, psiquicamente. Isso talvez explique por que mulheres mais velhas, que já saíram da menopausa, já possuem capacidades xamânicas, subitamente reveladas agora que podem usar de modo seguro um corpo que não mais "putrefaz" ou "refaz" a substância alienígena, mas que desintoxica internamente (cura) as substâncias venenosas ingeridas por outras pessoas e extraídas delas ${ }^{15}$. Ou como formulam os Ikpeng: um corpo que não mais "faz sangue". A aproximação entre o complexo gestação-menstruação e xamanismo também opera em reverso: os xamãs (ptanom) desintoxicam substâncias hostis introjetadas, ou dardos (também ptanom), na região de seus abdomens, hospedeira da agência alienígena (um ou vários espíritos auxiliares, também ptanom) - uma seqüência de equivalências que surge em paralelo com a série < sêmen + leite materno + pasta de mandioca + 
mingau + carne > que faz o bebê pré e pós-parto. Assim, a agência hospedada pelo xamã (ou "impregnação alienígena") pode ser concebida como um anti-feto, uma incubação perpétua que também exige precauções e evitações do tipo couvade, que se não forem seguidas arriscam a ira e a partida do espírito interiorizado ptat (que, alternativamente, pode matar seu hospedeiro). Essa proteção em forma de couvade de uma agência alienígena internalizada também inclui periodicamente os parentes nucleares do xamã — pais e/ou irmãos e filhos.

\section{O menino submerso}

A pré-iniciação xamânica ikpeng começa cedo, na infância. O menino pequeno deve evitar comidas fortes e gordurosas, substituindo-as por remédios ( $\nexists u g u)$ - no caso, infusões feitas de raízes de plantas. Quando a iniciação começa mais tarde — na adolescência tardia ou início da idade adulta —, os xamãs produzidos são quase sempre considerados ruins ou maus (karake-bra), pois é muito provável que alguns dos parentes do neófito já tenham morrido: o futuro xamã conhece a morte e, portanto, já está tomado por uma raiva vingativa. Essa raiva poda qualquer talento para a cura, pois atrai o tipo errado de espírito.

A primeira fase da iniciação começa com meninos na infância tardia ou no começo da adolescência. A maior parte das comidas são evitadas, sendo admitidos apenas um mingau aguado feito de beiju dissolvido e alguns pássaros leves, em geral, jaós. Se o menino for mais velho, deve evitar também qualquer atividade sexual. Todas essas restrições se aplicam adicionalmente aos pais e germanos do noviço. Tais preparativos induzem ao fechamento somático do iniciante. Alguns dias antes do começo da iniciação, o noviço inala a fumaça de uma fogueira aromática de seiva de árvores e frutas, contendo, entre outras, resinas de jatobá e copaíba ${ }^{16}$. Nesse ponto, o neófito é esvaziado, todos os contatos com o exterior reduzidos ao mínimo, e seu corpo preenchido apenas com fumaça aromática (análogo ao preenchimento da menina com água durante seus primeiros mênstruos).

Os noviços são submersos periodicamente durante um período de cinco a seis meses. As submersões iniciais ocorrem à tarde e vão progredindo ao longo dos meses até o momento das sessões finais: estas devem ser executadas à meia-noite durante a lua cheia. Após a escolha de um córrego recluso e profundo, um noviço (ou dois, no máximo) mergulha na água, segura em um tronco de árvore no fundo do córrego, e fica olhando 
para a superfície, a alguns centímetros de sua face. Enquanto está nessa posição, os xamãs experientes que estão na margem deixam a resina de jatobá em brasa escorrer de uma cuia de casca da árvore para a superfície do córrego, um pouco acima de seus olhos. Em intervalos, o noviço nada para a superfície, respira e volta novamente para reiniciar o processo de derramamento de resina na superfície aquática. O termo preciso utilizado é enpṫ/pingar-nos-olhos, um verbo que também descreve a ação de pingar remédios vegetais nos olhos de um paciente que sofre de maus sonhos ou visão distorcida: só que, aqui, o líquido de jatobá desperta o xamã alhures. Enquanto o jatobá em brasa cai na água, seu aroma atrai e depois paralisa inúmeras espécies aquáticas que passam a flutuar em torno do iniciante em um estado de semitorpor. A primeira espécie a chegar é tempuya, o poraquê. Como vimos, foi ele o instrutor xamânico final de Imere. Em seguida, outros vêm se juntar ao noviço, na seqüência: anaconda, arraia, tartaruga, piranha, jacaré e várias espécies xamânicas minúsculas de peixes. Aparentemente mortos (na verdade, tongnore/bêbados/comatosos), os vários seres aquáticos "preenchem os ouvidos" do noviço com seu tumtankom/vozes ininteligíveis. A essa zoeira infernal é adicionado o som da resina fervente de jatobá entrando em contato com a superfície, bem como os barulhos da chuva e a chegada dos trovões provocados pelo começo da iniciação.

Esse tumulto atrai dois outros seres. O primeiro a chegar é Imere, na forma de uma violenta tempestade de raios, enraivecido pela suposta morte dos peixes. Os raios chamam a segunda figura: wot-imt/pai-do-peixe, fonte de todas as espécies de peixes — que saem da sua boca - , enorme e coberto de escamas multicoloridas. Ele também cai inconsciente e é fisgado da água pelos xamãs na beira. Eles raspam um pouco da camada grudenta que cobre sua pele e o jogam de novo na água. Durante todo esse tempo, o noviço emerge para respirar e retorna para o fundo da água em um ritmo contínuo por várias horas. Finalmente, o noviço sai do rio, gelado, exausto e coberto com a mesma camada translúcida, grudenta, agyuru (parecida com a camada que cobre peixes e certas espécies de árvores), e também com restos da resina de jatobá dissolvida na água, que, dizem, deixam um forte fedor no corpo do noviço. Altamente irritante, essa frágil pele-de-peixe/wot-pitu é, contudo, deixada intacta até que o noviço emergente se seque por completo. Os contatos com a superfície do corpo do noviço são reduzidos ao mínimo possível, seus membros permanecendo semiparalisados, esticados, seus olhos cegados pela água do rio e a resina, e seus ouvidos ainda ensurdecidos pela zoeira produzida pelos seres aquáticos e pela tempestade. A emergência do iniciante da água é 
um nascimento após a morte (após a vida), tendo em mente que, para os Ikpeng, esse recente nascimento também coloca o iniciante em um estado próximo aos mortos. Portanto, como os bebês, é como se ele estivesse quase morto, ainda exposto ao mundo dos espíritos. Seu corpo amareloclaro é fechado e selado por uma membrana, com todos os estímulos sensoriais externos diminuídos, restando apenas a reverberação do caos acústico em seus ouvidos: um abrigo para o barulho. Em certo sentido, os Ikpeng produzem uma flauta humana, escavada por dentro, ecoando a "inspiração" de agentes externos (feitas de espécies de bambu ribeirinho e guardadas debaixo d'água, as flautas ikpeng também emergem do rio). Ou, ainda, outro instrumento: uma cabaça diabólica, como Lévi-Strauss (1966) define a cabaça usada por demônios, submersa na água para capturar os humanos, fato relatado em várias culturas sul-americanas. Assim, o xamã seria o inverso do chocalho fúnebre que abriga a raiva dos futuros vivos ikpeng: o noviço faz-se o abrigo da raiva dos animais mortos ${ }^{17}$.

A tempestade passa. À medida que as várias espécies na água redespertam e dispersam, o iniciante também lentamente revive, enquanto o barulho em seu ouvido vai gradualmente se resolvendo em sons inteligíveis, agora reconhecíveis como música-demoníaca/wonkin-eremrti. Esse é o primeiro resultado antecipado (acústico): através de um fechamento somático e sensorial extremo - com a boca e o nariz tapados, os olhos marejados de água e fogo, flutuando submerso "diabolicamente" —, o iniciante torna-se um instrumento para ouvir/compreender (ira) a normalmente inaudível ou ininteligível linguagem de outras espécies. Após essa fase da iniciação, os espíritos dos vários animais e espécies de peixes também começam a reconhecer o xamã, contendo a usual hostilidade com que respondem aos humanos e permitindo a comunicação, ou melhor, a contaminação acústica, inclusive sua aquisição de eremrṫ/cantos/música durante sonhos e jornadas na floresta.

O "fechamento" do iniciante também possibilita sua "introspecção". Só que ao se olhar por dentro, preso nas imagens caóticas estimuladas pelo jatobá em brasa e pelo cansaço extremo, ele descobre um espaço vasto e populoso. Isso tem um segundo resultado (visual): o mundo espiritualvirtual (passado e futuro) começa a se tornar transparente para ele. Finalmente, o terceiro resultado (olfativo): após remover sua camada seca, o noviço é banhado e depois pintado com urucum-de-xamã, uma poção feita de pequenas quantidades de urucum e outros extratos de frutas e seiva de árvores, que é juntada à camada de pele extraída do pai-do-peixe e espalhada finamente sobre a pele do iniciado. A aplicação dessa pasta como se fora um tipo de cosmético antecipa a futura técnica xamânica que 
permite que a substância interiorizada em seu estômago venha à tona em sua saliva, processo possibilitado pela micropopulação de ptanom agora em seu estômago. Essa substância é mais tarde espalhada sobre a pele de um paciente, seu aroma (ebragru) agindo como um remédio, um "antiafeto" em relação ao elemento alienígena afetando a carne do paciente (imnu). Se aplicada em excesso, a pasta desnaturaliza e seu efeito é alterado: de medicinal passa a ser venenoso, e o xamã torna-se letal, matando seus pacientes ou - quando de forma deliberada, o que não é sempre fácil de avaliar, nem para ele ${ }^{18}$ — seus inimigos.

Por estar vedado às comidas — produtos da violência ikpeng - e, assim, à afirmação humana, o novo xamã age como um receptáculo de zoeira e fedor (Lévi-Strauss 1966), um conduto de afeto inumano. Uma pessoa estragada, ele desaparece da humanidade. Os Ikpeng descrevem o xamã como não-humano: mais exatamente, uma ex-pessoa/tenpanoptn. Também o chamam simplesmente de diferente/toroyon. Embora excepcional de muitas maneiras, essa diferença absoluta antecipa seu destino último: ao contrário de todas as outras pessoas, o xamã evita uma morte celestial ou, em outras palavras, a captura, moqueação e consumo de seu reflexo/egaron-ptn por espíritos e a subseqüente absorção pela massa anônima e alienada dos mortos que habitam o céu. Ele se desvia desse destino na segunda fase da iniciação, durante a qual visita o mundo celeste e anuncia aos seus habitantes sua intenção de jamais retornar. Os mortos lhe oferecem comida - beiju avermelhado e carne de anta (apontada pelos Ikpeng como incomível, já que a anta é humana). Embora finja estar comendo, o xamã na verdade esconde a comida em sua bolsa: ao retornar à floresta, essas comidas aparecem como fungos e pedras, dos quais são feitas várias poções xamânicas. Pode-se dizer, portanto, que a ex-comida dos mortos proporciona vida.

Após essa visita, uma série de mudanças instala-se em sua vida até o final, culminando com um evento bastante extremo: o xamã é enterrado vivo. Com seu consentimento, a tampa de sua tumba-terrestre é selada com casca de jatobá - utilizada no passado para a manufatura rústica de canoas, hoje para receptáculos para a cerveja fabricada para os rituais ${ }^{19}$. Após o enterro, seu corpo fragmenta-se na medida em que os ptanom, ou seja, as agências xamânicas auxiliares, rompem sua pele e se dispersam na floresta, evasivos e imortais. Os xamãs vivos podem conclamar essas agências xamânicas (efetivamente partículas dos xamãs mortos) para apoio, capturando e hospedando-as em vários itens secretos e substâncias encontradas na floresta ou transmitidas a gerações de xamãs. Os xamãs formam, portanto, uma genealogia secreta, imortal mas impessoal, en- 
quanto a população ikpeng continua mortal e nomádica, em um sentido genérico. A profundidade genealógica é cancelada por uma lógica da substituição/renovação (suplementação), em que a reprodução orgânica é eclipsada por uma noção de captura e, finalmente, perda ${ }^{20}$.

O mito ikpeng que descreve a origem da prática de enterrar o xamã vivo envolve um evento significante: após seu enterro, Yamra envia um eclipse solar, a lua sangrando o sol e criando uma fenda no céu, expondo assim o mundo dos mortos e sua lamentação insuportável. A lua é convencida a caçar e matar alhures pelo filho de Yamra, que flutua rio abaixo e à deriva, assoviando com seus dedos (imitando caça) ${ }^{21}$. Esse detalhe, portanto, implica que a fraturação do corpo do xamã é um tipo de menstruação cósmica, uma liberação final de sua "gravidez perpétua" dos ptanom contidos (ou agências xamânicas), agora novamente espalhados e à deriva pela floresta.

\section{Anomalia e patriz}

Esses pequenos objetos xamânicos que povoam o cosmos são chamados $i m \dot{t}$ - um nome que nos remete ao pai-do-peixe (wot-imt $)$, encontrado durante a iniciação no rio. De fato, wot-imt também aparece como uma pedra calcária, agora em posse de um dos xamãs mais experimentados. Ele mistura uma pequena quantidade do pó dessa pedra com água e dá para as crianças pequenas que estejam com enjôo devido à ingestão de peixe. Inúmeras outras pedras e crânios de animais são usados de maneira semelhante: tartwe-imt (uma pequena chapa de pedra) para o crescimento da mandioca, tuya-imt (um crânio de roedor) para dor de dente. Entretanto, o termo imt́t também se aplica aos vários "mestres de animais" com quem o xamã pode negociar a liberação de presas de caça. Isso inclui o enorme e reluzente pai-do-peixe. Porém, o principal desses seres é ałia$n a-i m \dot{t}$, pai-do-queixada, uma versão minúscula de um queixada que contém todos os novos queixadas dentro de si, liberando-os (ou recolhendoos) de sua boca com um grito. No passado distante, os Ikpeng apanharamno e tentaram domesticá-lo a fim de criar um acesso fácil às presas. Mas ele conseguiu escapar tanto de uma casa-na-árvore quanto de um abrigo no fundo de um lago, escondendo-se primeiro entre as pernas de sua prole maior (como um filhote protegido por sua mãe), e depois correndo pela floresta, sumindo (aluku), deixando apenas uma pista falsa, que os humanos seguiram em vão. Agora, ele mora longe da humanidade, é conhecido apenas pelos xamãs, ao passo que seus filhos são nômades na floresta. 
Notavelmente, os Ikpeng dizem que o queixada é incapturável, pois seu faro agudo e seu senso do subsolo, onde cava para obter sua comida, alertam-no para o buraco ardiloso (yana) armado pelos Ikpeng. O pai-doqueixada vem aqui se somar como uma estranha possibilidade: em um certo sentido, ele cai em sua própria armadilha - um animal autocaptor. Essa autocaptura explica a fórmula, aparentemente estranha, que propõe que um animal minúsculo libere ou retenha sua prole - que é maior em tamanho (ou melhor, do tamanho normal) — através da abertura ou fechamento de sua boca, e se proteja no "espaço interno" produzido pelas pernas de seus filhos. Esse mito fornece um conceito coerente, ainda que estranho: a noção de um "suplemento original" - um patriz ${ }^{22}$. O pai-do-queixada substitui e desatualiza uma genealogia ou reprodução "natural" (ver Taylor 2000). Nessa lógica, o sucessor já era um protótipo do anterior ${ }^{23}$.

Todos os pais-de-espécies nomeados pelos Ikpeng parecem versões aberrantes e xamânicas de sua prole "natural". Tal feição alinha-os a outros conjuntos de anomalias de espécies. Da mesma forma que outros povos amazônicos, os Ikpeng têm um extenso corpo de conhecimentos sobre a floresta e sua respectiva fauna. Ainda assim, por vezes, novas espécies são encontradas. Quando isso ocorre, a espécie é geralmente aproximada de uma espécie já conhecida e nomeada através da adição do sufixo yum (tal como tereng-yum, a abelha "europa", chegada só recentemente à região do Xingu). Este sufixo funciona, então, como uma espécie de agente preliminar de absorção de novas variantes no léxico ikpeng. Entretanto, a sufixação também carrega uma profunda associação com o perigo: tudo o que é yum, afora essas recentes adições, se refere a predadores altamente perigosos, tais como tunan-yum, capivara-monstro, ou malula-yum, tatu-monstro.

Neste ponto surge uma série de traços etnológicos bastante intrigantes. Ambos os termos imt e yum são cognatos caribe - termos para idéias similares em inúmeros outros povos caribe. Os sufixos wayana são, na verdade, inversões dos ikpeng: yum indica um "pai-de-espécie" (Hurault 1968:16), enquanto imt denota uma forma "enorme" ou "monstruosa" de uma certa espécie (van Velthem 1995:41; ver também Waiwai imo, "épico", "grande"; Kalina imo, "formidável" )24. Assim, se fizermos uma compilação desses tipos de anomalia, veremos surgir uma seqüência incomum: novos e desconhecidos, anômalos, xamânicos, paternos. A isso podemos adicionar o corpo ardiloso e/ou abrigador - isto é, arquitetural — indicado na narrativa ikpeng sobre o pai-do-queixada. Se tomarmos essas considerações como um todo, penso que elas nos podem fornecer uma figura genérica comum aos povos caribe, onde cestas (feitas por 
homens e predatórias) (ver Guss 1989), armadilhas, flautas, malocas e outras estruturas se organizam em torno de uma função paternal (pai/ sogro) de abrigo e controle da contenção e liberação de conteúdos ${ }^{25}$.

Claramente, o análogo humano dessa figura é o líder da maloca ou aldeia, o ápex social, que em muitos casos nas Guianas - e entre os Ikpeng — pode ser também o xamã principal (ver Rivière 1984). Assim, o líder/xamã humano é um equivalente dos pais-das-espécies, cada um formando uma versão anômala de sua população. Essa noção é estendida na idéia ikpeng da fontanela como o ponto de emergência inicial do crescimento fetal: esse ápex do corpo (uma abertura bocal nos bebês) é também nomeada "nosso pai". O ponto onde se dá a primeira coagulação do sêmen. Devemos notar que o conceito ikpeng de paternidade múltipla (muitos homens podem fazer um feto) implica que essa origem pode sempre ser potencialmente suplementada pelo estrangeiro e pelo desconhecido.

\section{Conclusão}

E quanto às mulheres? Essa questão nos leva a um dilema bastante típico da etnologia amazônica: embora os Ikpeng tendam freqüentemente a enfatizar um equilíbrio sexual necessário na produção doméstica de um casal, as funções e posições masculinas - especialmente na caça e na guerra - parecem ser dominantes. Penso que isso é um paradoxo ilusório. Como argumentei acima, a diferença sexual opera de dois modos: orgânico e não-orgânico - quanto a este último, trata-se de potência cosmopolítica, não poder sociopolítico. Essa diferença fundamental revela uma potência feminina algo escondida. Se a função masculina/paterna é uma forma de contenção arquitetural, a função feminina/materna corresponde ao conteúdo - à espécie (humana ou outra) como matriz populacional. Esse, um potencial rizomático como o corpo fluido das formigas ou o crescimento subterrâneo dos tubérculos da mandioca: substanciais, múltiplos, obscuros e quietos (geralmente enterrados/contidos), uma vitalidade olfativa e visual (cosmética) comunicativa, fluidamente interconectada, propagativa e heterogênea. Um bando, enxame ou pack: um conceito que poderíamos, por conveniência, chamar de proto-animista, o que difere dos conceitos humanistas acerca do sociopolítico.

As espécies-patrizes masculinas constituem o receptáculo ou abrigo arborescente dessa população ou bando feminino: sua forma arquitetural envolvente e seu modo visível-audível de singularização. O ápex social de uma população local (ou maloca) é também chamado de ebru, termo 
polissêmico usado para designar líder, grito/riso, suporte, base ou estrutura, um rótulo vocal ou ponto de convocação. Um ponto de coerência exterior. A anomalidade potencial dos homens (como chefes, xamãs ou guerreiros) tende, em certo sentido, a ejetá-los do socius "feminino", apenas para então configurá-los como vários tipos de aliados, visitantes perpétuos de seu próprio povo, contingência atualizada em microescala cada vez que um caçador retorna para a maloca ao anoitecer.

A identidade ikpeng (como a visibilidade temporária de suas "afecções" como um povo) é produzida precisamente por essas visitações retornantes - caçadores carregados de caça, guerreiros carregados de produtos inimigos e crianças, xamãs carregados de cantos de espíritos. Mas esse retorno é seduzido pelas mulheres. São os seus desejos que impelem os homens a sair e retornar, são elas que, em última instância, capturam todos os produtos externos - uma afirmação tornada visível durante o período dos rituais, quando as mulheres mais jovens atacam os caçadores que retornam à aldeia, puxando a caça de seus ombros e os peixes de suas mãos - , uma recaptura pseudoviolenta chamada inpuan, apanhamento (ver foto 2).

As mulheres despertam os Ikpeng como povo. Tanto pela manhã, quando elas acendem os fogos e preparam a primeira leva de beiju, quanto à noite (durante os rituais), quando as mulheres mais jovens arrancam os homens de suas redes para dançar ou ter sexo. Se as posições masculinas diferenciam um potencial relacional, os vetores femininos compõem um potencial afeccional. Elas ativam e projetam a população em seus vários modos ou blocos de atividade: roça, maloca, caça, guerra, dança, luto... É assim que entendo o problema da aparente não-obsolescência dos conceitos de sociedade e indivíduo na etnologia amazônica, apesar do consenso no que diz respeito à inadequação do seu contraste como operador analítico (ver Strathern 1988). No pensamento ikpeng, o socius não está delimitado por um cálculo relacional que define os limites de um grupo, mas por um modo comportamental que compõe um espaço provisional: uma formação-bando - um bloco social fluido, mas heterogêneo, capaz de capturar e integrar novos elementos. Isto está simultaneamente acompanhado por uma figura singular, uma anomalia populacional (e sociopolítica), o líder - figura ao mesmo tempo apical e envolvente, sem poder político mas com potência cosmológica.

Em minha explicação anterior do termo "ikpeng", omiti um detalhe crucial: a palavra também designa a metamorfose pupal que, conjeturase, ocorre como pausa ou intervalo entre as modulações formiga e vespa. A que corresponde então tal fase? Encapsulada, oculta e intensiva, indica 


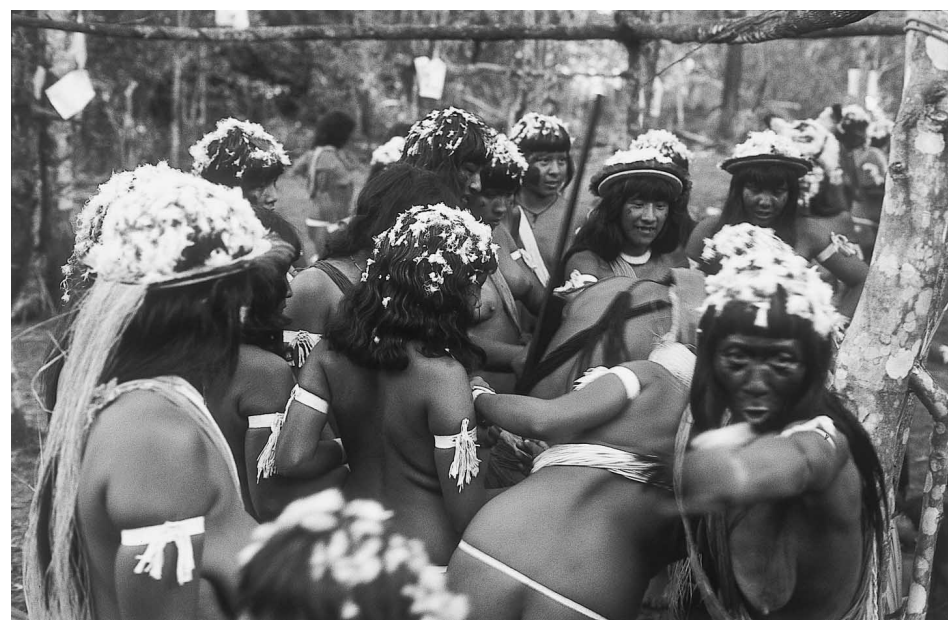

2

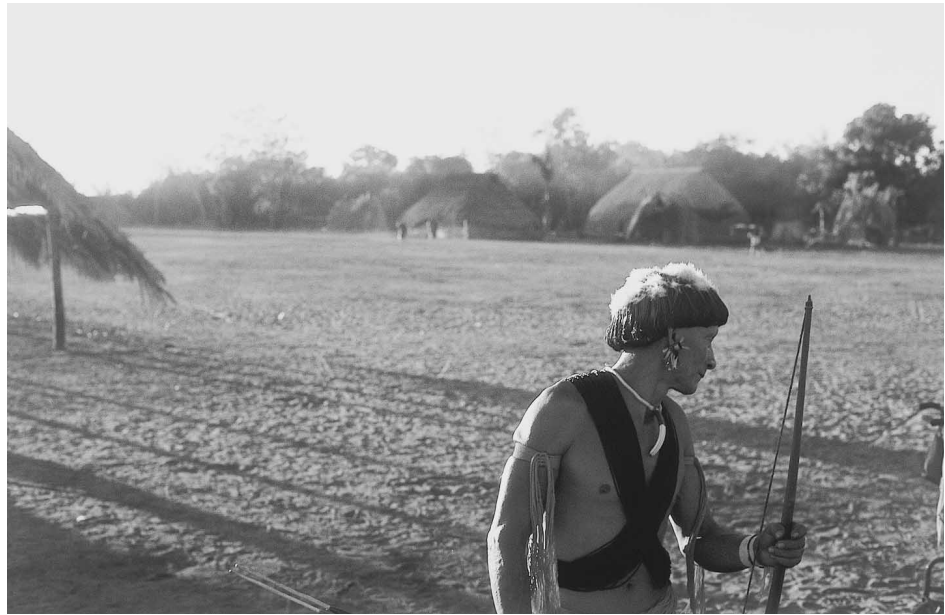

3

2

Yampo, líder das mulheres, guerreira, coordenando o apanhamento e distribuição dos animais moqueados no fim da caça ritual wonpongna. Note-se a cobertura de penugem nas cabeças das mulheres. O carvão espalhado no rosto de Yampo indica seu status pós-menstrual.

3

Melobo, líder do povo ikpeng e xamã principal, procurando espíritos ao redor da maloca grande antes de um ritual: o resto da população já está dentro de casa. Note-se a leve cobertura de penugem em sua cabeça. 
duas possibilidades não-extensivas (isto é, que não exploram a topologia local de mata, roça, rio): a gestação feminina e a incubação xamânica. Essa fase pupal é chamada tṫwonptam, a palavra para crisálida, lagarta, pupa, mas também para a penugem dos pássaros e aves, um termo traduzível como "asas-virtuais" 26 .

Isso nos remete a uma das cenas principais do inverno ikpeng. Normalmente inconspícuo, o xamã surge como ponto focal durante os momentos mais intensos dos rituais ikpeng, quando ele canta a primeira "música demoníaca" que ouviu em sua iniciação, a qual retorna, se desenvolve e multiplica mais tarde em seus sonhos. Agora, o xamã é descrito como novo (enu) e permanece atado à maloca, emergindo apenas ao amanhecer. Essa música é ecoada por um bando de mulheres e meninas que andam atrás dele na maloca, capturando (ainku) e reiterando o discurso alheio. Enquanto parte da maloca está tomada por uma fila de corpos mascarados e decorados com restos de inimigos e animais capturados nas mais diversas profundezas temporais, os únicos humanos visivelmente presentes são o xamã solitário e o enxame de mulheres — não-mascarados, apenas suas cabeças cobertas levemente com penugem de pássaros (ver fotos 2 e 3) - , assinalando e possibilitando a receptividade: a alimentação externa de cantos, saúde e vitalidade, primeiro adquirida e desintoxicada pelo xamã. Confinado e quase invisível no interior escuro da maloca, o xamã emerge como um ponto de ressonância e coerência para o seu povo, uma fonte-fontanela aberta para o futuro: tenpano-ptn e enu, já pós-humano e novo. Sempre nômades, os Ikpeng ainda ficam por nascer.

Tradução de Ana Paula Ratto de Lima

Recebido em 18 de janeiro de 2002

Aprovado em 15 de agosto de 2002

David Rodgers fez graduação em Artes Plásticas na Universidade de Oxford, Inglaterra, e mestrado no Departamento de Antropologia Social da Universidade de Manchester. Atualmente, está terminando seu doutorado na mesma instituição sobre o pensamento e a sociocosmologia do povo ikpeng. E-mail: davidrodgers@alternex.com.br. 


\section{Notas}

* Este texto é fruto de uma adaptação de algumas partes de minha tese de doutorado em preparação (Universidade de Manchester), baseada em dez meses de pesquisa de campo realizada entre 1996 e 1999 com auxílio do ESRC/Reino Unido. Uma versão inicial foi apresentada no Seminário de Etnologia Indígena realizado no IFCS/UFRJ, Rio de Janeiro, em setembro de 2001; agradeço a Aparecida Vilaça, Elsje Lagrou, Marco Antonio Gonçalves e Tânia Stolze Lima pela oportunidade. Gostaria de agradecer aos professores do PPGAS/Museu Nacional por sua hospitalidade desde minha chegada ao Brasil em 1996, e particularmente no ano de 1999, quando fui pesquisador associado nessa instituição. Agradeço especialmente a Bruna Franchetto e Marcio Goldman por seu apoio tanto institucional quanto pessoal. Agradeço, sobretudo, a Ana Paula Ratto de Lima por sua ajuda indispensável e inspiração no desenvolvimento de vários aspectos do presente texto. Finalmente, agradeço aos Ikpeng por sua incondicional hospitalidade, e a meus amigos e informantes principais, no que diz respeito a este ensaio Melobo, Awato, Agiwo, Oporike -, por sua paciência em acompanhar minhas tentativas de entender o mundo não às avessas.

1 Este tópico foi explorado em termos dos sistemas de parentesco e de nominação txicão-ikpeng por Patrick Menget (1977; 1988).

${ }^{2}$ A meu ver, o uso do conceito de socialidade (Strathern 1988) já se tornou problemático: ao ser tratado como qualidade do social, fica suscetível a uma redução moral que conservaria as virtudes simples, que - ao que parece - nunca foi o propósito original de Strathern. Não sei se é recuperável para uma antropologia baseada na diferença intensiva a priori do humano.

3 Até onde eu sei, trata-se da combinação da formiga tocandira (Paraponera clavata: arayo em ikpeng) com uma espécie não identificada de vespa (turum em ikpeng), ambas picadoras. Diz-se que as formas do corpo são quase idênticas. Eu consegui ver apenas as formigas e os ninhos das vespas, não as próprias vespas.

4 Em congruência com essa noção, entre os Wayana, a trilha tomada pelo morto para o céu é intercalada com uma seqüência de insetos picadores (van Velthem 1995).

5 Modulação funerária/guerreira (queimada) em vez de caçadora (crua): na verdade, confrontada com o material arara e de várias outras culturas caribe, essa proposição parece apontar para um deslocamento geral na transmutação culinária das substâncias através dos planos sociocosmológicos identificados pelos Ikpeng.

6 O verbo iruku corresponde a: iru + uku = "choro+imitar/experimentar/devir" (sobre $u k u$, ver adiante). 
7 Lévi-Strauss (1966; 1971:493) fala da oposição entre arraias (reservatórios de sangue) e morcegos (consumidores de sangue) em vários pontos.

8 Os mitos ikpeng são sempre concebidos como a "fala de fulano" (fulanomuran), e suas versões mais remotas nomeadas coletivamente de "fala de animaldemônio" (wonkinom-muran).

9 A fenomenologia, invariavelmente, confunde a percepção (de fenômenos) com a consciência como autociência ou "presença-para-si": um tipo de autopercepção atingido através de uma escuta da "voz interior" como "pensamento consciente" (presumida como a do próprio sujeito - um equívoco que os Ikpeng não cometeriam) (ver Derrida 1967 sobre Husserl). Daí, talvez, a corrente idealização do discurso e da consciência como as únicas fontes do conhecimento autêntico na fenomenologia amazônica (cf. Overing e Passes 2000).

10 O sufixo - pe encontra-se também na língua arara (a mais próxima da ikpeng), indicando "um estado ou uma qualidade" (Teixeira-Pinto 1997:55, n. 5). $\mathrm{O}$ autor nota que ele é usado freqüentemente nos nomes das festas arara. Parece ser um cognato caribe geral: compara, por exemplo, o sufixo trio -me, que Rivière (2000:255) traduz como "being".

11 Ou substancialização da aparência - isto é, o corpo/carne - dado que a sombra/reflexo é descrita pelos Ikpeng como a carne-verdadeira: eram imnu. Devemos notar que tanto o corpo/carne/imnu, quanto a alma/sombra/egaron-pinn, são aspectos passivos e, assim, negativos: a potencial atualização de alguém ikpeng como a comida dos outros (dos animais predadores ou dos canibais no céu). Os aspectos ativos e positivos ikpeng são localizados alhures.

12 Parafraseando Nietzsche (1995), a verdade é o tipo de erro sem o qual uma certa espécie de vida não poderia viver. O oposto diametral do tipo de escapamento ou fuga nomeada por aluku é uma automaterialização, oruku, a forma reflexiva do verbo $u k u$, literalmente um "autodesenhar" ou "autopoiesis". O termo aplica-se às aparições espontâneas de seres demoníacos e espécies inimigas em trechos estranhos da floresta ou em redemoinhos em rios e lagos. Isso também se aplica à produção tecida de efígies xamânicas, estas denominadas yukutpot (forma substantiva do verbo $u k u)$.

13 Termo difícil de analisar, mas que parece conter as raízes $u k u$ (ver acima) e anum (pegar, tirar, levantar), talvez indicando uma abdução por outro povo/espécie, combinada com uma ascensão associada à morte (ver Hirtzel 1997:51 sobre o termo ritual wayana t-anuk-ta-i, "métamorphoser").

${ }^{14}$ Idéia que vem de Nietzsche (1992[1886]:§32).

15 Ver, também, Vilaça (2002:360) sobre os Wari', e Belaunde (2000:219, n.5) sobre os Airo-Pai. 
${ }^{16}$ Essas emanações são fragrâncias da beleza crua/fresca do mundo subaquático, uma mistura que contrasta com o fedor putrefato e decadente liberado pela fogueira quando o xamã ascende para o mundo celeste dos mortos: aqui, a ascensão é preparada com a inalação de plantas, queimando, inclusive, folhas de tabaco.

17 Os chocalhos - makai - são duas irmãs novas (pubescentes) que espantam o fantasma do morto: coisas-para-fazer-sumir/alukunoptowo. Homens jovens não podem tocá-los, pois fatalmente desmaiariam, um efeito cuja implicação (suponho) é a de que seu contato seria incestuoso: repletos de sementes, sua fertilidade é assim exteriorizada - incentivo para que os guerreiros retornem com seus inimigos mortos e capturados. Quanto ao novo xamã, penso de fato que as duas possibilidades coexistem e se confundem: um par flauta-humana/cabaça-diabólica seria $a$ armadilha dupla feita pela iniciação (ver Gell 1996), presa e predador em um só corpo. Ele configura um ponto de convergência radical na sociocosmologia ikpeng. Outro ponto crucial, que infelizmente não poderei discutir aqui com alguma profundidade, é o da mulher demoníaca Enoy: ela engole caçadores solitários através de seu umbigo, após as frustradas tentativas destes últimos de ter sexo com ela, já que sua vagina está bloqueada/ausente. Mais uma vez, um corpo-como-armadilha - e uma imagem do incesto materno como implosão catastrófica.

18 Como veremos, o xamã é um ser múltiplo, uma micropopulação de agências xamânicas abrigada em um corpo: portanto, nem suas "intenções" são jamais exclusivamente "suas", nem ele está nunca certo de suas próprias intenções. Um outro povo caribe, os Waiwai, nomeia de fato o xamã singular como um ser múltiplo, yaskomo, aproximadamente "povo mágico/xamânico" (Fock 1963:123). O autor atribui essa, aparentemente, curiosa pluralização do xamã à sua "condição institucional", pressupondo que o xamanismo é uma instituição. Suspeito, entretanto, que os Waiwai estejam, na verdade, apontando para uma pluralidade não-humana contida no xamã singular, liberada por ocasião da morte (Fock 1963:166).

${ }^{19}$ Em comunicação pessoal, Márnio Teixeria-Pinto informou-me que os Arara costumavam cercar as mulheres menstruadas com casca de jatobá. Ainda não tive a oportunidade de sondar essa idéia com os Ikpeng, mas se conjugarmos essa informação com o uso ikpeng de canoas de jatobá para conter cerveja de milho ritual, a casca dessa árvore (Hymenaea courbaril) parece funcionar como um abrigo/ receptáculo para o "divino". (Na cremação wayana, os olhos dos mortos mutilados são similarmente cobertos com casca de jatobá (Hurault 1968:64).) Em relação a esse elo caribe, podemos notar também que a resina de jatobá freqüentemente contém insetos preservados. Até onde posso supor, essa forma de enterro se aplica apenas àqueles xamãs que visitaram o céu. Dizem que o último desses enterros aconteceu na década de 80 com a morte de Pabru, um xamã poderoso, além de líder dos Ikpeng, na época. Fock (1963:166-167) descreve o exemplo de um xamã enterrado vivo entre os Waiwai.

${ }^{20}$ Ver Taylor (2000) para um conjunto de idéias semelhantes entre os Jivaro. 
${ }^{21}$ A lua é descrita como caçador de humanos pelos Ikpeng, e por isso é afastada quando cheia.

22 No uso técnico-industrial, o termo patriz denota uma moldura ou padrão positivo utilizado para produzir uma matriz: esta última é um molde negativo usado para produzir uma cópia (a cópia sendo assim o negativo do negativo). A patriz, dessa forma, substitui o "original" a ser copiado no fim da seqüência: original/PATRIZ $\rightarrow$ MATRIZ $\rightarrow$ PROLE/original. Só que, como o mito indica, somente o substituto (a anomalia) jamais existiu, existe e existirá. Como Nietzsche apontou em sua nova genealogia, o original seria nosso mito.

${ }^{23}$ O pai-do-queixada - ou mestre-do-queixada - cumpre uma função crucial no eixo caça-xamanismo em vários grupos caribe (e alhures) (ver, particularmente, Fock 1963 e Rivière 2001).

24 Parece que essa estranha inversão acontece entre os povos arara e pelo menos os caribe do norte da Amazônia: também em arara, imu designa pai. Porém, o termo arara para "mestre-da-espécie" é oto (Teixeira-Pinto 1997), um cognato do ikpeng yoro/dono/provedor, exceto que os Ikpeng usam esse termo para um dono de tipo diferente da espécie ou substância possuída: as abelhas são yoro do tabaco, os humanos são yoro do mingau de mandioca...

25 Isso se aplica, por exemplo, ao líder de caça ikpeng, wogyoro, que direciona a caça sem participar nas matanças, além de defumar e tomar conta da presa quando ela chega, e, finalmente, supervisiona cuidadosamente sua chegada na aldeia em uma enorme cesta carregada pelos caçadores, cuidando para que ela não toque o chão - em suma, o wogyoro se configura como o líder/patriz de uma população suspensa de animais mortos (preservados pela moqueação).

26 tíwonpiam: tíwon (asa) + piam (ex/virtual: plural) 


\section{Referências bibliográficas}

BELAUNDE, Luisa Elvira. 2000. "The Convivial Self and the Fear of Anger amongst the Airo-Pai of Amazonian Peru". In: J. Overing e A. Passes (orgs.), The Anthropology of Love and Anger. The Aesthetics of Conviviality in Native Amazonia. London: Routledge. pp. 209-220

DELEUZE, Gilles e GUATTARI, Félix. 1980. Mille Plateaux. Capitalisme et Schizophrénie. Paris: Les Éditions de Minuit.

.1991. Qu'est-ce que la Philosophie? Paris: Les Éditions de Minuit.

DERRIDA, Jacques. 1967. La Voix et le Phénomène. Paris: Quadrige/PUF.

FAUSTO, Carlos. 2001. Inimigos Fiéis: História, Guerra e Xamanismo na Amazônia. São Paulo: EDUSP.

FOCK, Niels. 1963. Waiwai: Religion and Society of an Amazonian Tribe. Copenhagen: The National Museum.

GELL, Alfred. 1996. "Vogel's Net: Traps as Artworks and Artworks as Traps". Journal of Material Culture, 1(1):1538.

GOW, Peter. 1997. "O Parentesco como Consciência Humana: O Caso dos Piro". Mana, 3(2):39-65.

GUSS, David. 1989. To Weave and Sing. Berkeley: University of California Press.

HIRTZEL, Vincent. 1997. Les Métamorphoses Humaines et Animales dans la Mythologie Wayana. Mémoire de Maîtrise, Ethnologie. Université de Paris X - Nanterre.

HURAULT, Jean. 1968. Les Indiens Wayana de la Guyane Française. Paris: Orstom.

JARA, Fabiola. 1996. El Camino del Kumu. Ecología y Ritual entre los Akuriyó de Surinam. Quito: Abya-Yala.
LÉVI-STRAUSS, Claude. 1962. La Pensée Sauvage. Paris: Librairie Plon. . 1966. Du Miel aux Cendres. Paris: Librairie Plon. .1971. L'Homme Nu. Paris: Librairie Plon.

LIMA, Tânia Stolze. 1996. "O Dois e seu Múltiplo: Reflexões sobre o Perspectivismo em uma Cosmologia Tupi". Mana, 2(2):21-47.

MENGET, Patrick. 1977. Au Nom des Autres. Classification des Relations Sociales chez les Txicão du HautXingu. Thèse de 3 eme Cycle, Université de Paris-X, Nanterre.

.1988. "Note sur l'Adoption chez les Txicão du Brésil Central". Anthropologie et Sociétés, XII(2):63-72. NIETZSCHE, Friedrich. 1992 [1886]. Além do Bem e do Mal. São Paulo: Companhia das Letras.

. 1995. La Volonté de Puissance (I \& II). Paris: Gallimard.

OVERING, Joanna. 1990. "The Shaman as a Maker of Worlds: Nelson Goodman in the Amazon". Man (n.s.), 25: 601-619. e PASSES, Alan. 2000."Introduction. Conviviality and the Opening up of Amazonian Anthropology". In: J. Overing e A. Passes (orgs.), The Anthropology of Love and Anger. The Aesthetics of Conviviality in $\mathrm{Na}$ tive Amazonia. London: Routledge. pp.1-30.

REICHEL-DOLMATOFF, Gerardo. 1975. The Shaman and the Jaguar. A Study of Narcotic Drugs among the Indians of Colombia. Philadelphia: Temple University Press.

RIVIÈRE, Peter. 1984. Individual and Society in Guiana. A Comparative Study of Amerindian Social Organization. 
Cambridge: Cambridge University Press.

.2000. "The More We Are Together...". In: J. Overing e A. Passes (orgs.), The Anthropology of Love and Anger. The Aesthetics of Conviviality in Native Amazonia. London: Routledge. pp. 252-267.

— . 2001. "A Predação, a Reciprocidade e o Caso das Guianas". Mana, 7(1):31-53.

SPINOZA, Benedict de. 1996. Ethics. London: Penguin Books.

STRATHERN, Marilyn. 1988. The Gender of the Gift. Berkeley: University of California Press.

TAYLOR, Anne-Christine. 2000. “Le Sexe de la Proie. Représentations Jivaro du Lien de Parenté". L'Homme, 154155:309-334.

TEIXEIRA-PINTO, Márnio. 1997. Ieipari. Sacrifício e Vida Social entre os Índios Arara (Caribe). São Paulo: Editora Hucitec/ANPOCS.

VAN VELTHEM, Lúcia Hussak. 1995. O Belo É a Fera: A Estética da Produção e da Predação entre os Wayana. Tese de Doutorado, Departamento de Antropologia/Universidade de São Paulo.

VILAÇA, Aparecida. 2002. "Making Kin Out of Others". Journal of the Royal Anthropological Institute, 8(2):347365.

VIVEIROS DE CASTRO, Eduardo. 1996.

"Os Pronomes Cosmológicos e o Perspectivismo Ameríndio". Mana, 2(2):115-144.

. 2000. "Atualização e Contra-Efetuação do Virtual na Socialidade Amazônica: O Processo de Parentesco". Ilha, 1:5-46. 


\section{Resumo}

Este ensaio pretende examinar vários aspectos da sociocosmologia dos Ikpeng, povo ameríndio do sul da Amazônia. Através de um esforço de absorção de vários conceitos ikpeng em seu vocabulário analítico, ele explora a convergência das noções de afeto (não de relação) e de devir (não de transformação) desse povo em um plano sociopolítico composto por uma mistura de povos e espécies (não de pessoas). Nesse plano, o xamã figura como uma anomalia de espécie, posição alcançada pela sua exposição à morte múltipla, versão radicalizada da auto-intoxicação do sujeito ao longo da vida. Sustentadas por uma cosmologia animista/xamânica, tais concepções se provam incompatíveis com os modelos humanistas do sociopolítico predominantes na antropologia contemporânea. Seguir essa linha de pensamento indígena expõe também uma modelagem não-orgânica de diferença sexual intrínseca às composições transespecíficas envolvidas nos rituais ikpeng, mas cujos primeiros pontos de emergência são a iniciação xamânica dos meninos e a menstruação das meninas.

Palavras-chave Etnologia Amazônica, Xamanismo, Menstruação, Cosmologia

\section{Abstract}

This essay examines various aspects of the sociocosmology of the Ikpeng, an Amerindian people of southern Amazonia. Through an attempted absorption of various Ikpeng concepts into its analytic vocabulary, it explores the convergence of the notions of affect (not relation) and becoming (not transformation) of this people on a sociopolitical plane composed by a mixture of peoples and species (not persons). On this plane, the shaman figures as a species anomaly, a position achieved via his exposure to multiple deaths, a radicalized version of the self-intoxication experienced throughout a subject's lifetime. Sustained by an animistic/shamanic cosmology, these conceptions prove incompatible with the humanistic models of sociopolitics predominant in contemporary anthropology. Following this indigenous line of thinking also exposes a non-organic modelling of sexual difference, intrinsic to the trans-species compositions involved in Ikpeng rituals, but whose first points of emergence are the shamanic initiation of boys and the menstruation of girls.

Key words Amazonian Ethnology, Shamanism, Menstruation, Cosmology 